\title{
A New Transit Safety Narrative
}

\author{
Todd Litman \\ Victoria Transport Policy Institute
}

\begin{abstract}
Public transportation is, overall, a relatively safe (low crash risk) and secure (low crime risk) transport mode. Transit travel has about one-tenth the traffic casualty (injury or death) rate as automobile travel, and residents of transit-oriented communities have about onefifth the per capita crash casualty rate as in automobile-oriented communities. Transit also tends to have lower overall crime rates than automobile travel, and transit improvements can help reduce overall crime risk by improving surveillance and economic opportunities for at-risk populations. Despite its relative safety and security, many people consider transit travel dangerous and are reluctant to use it or support service expansions in their communities. Various factors contribute to this excessive fear, including the nature of transit travel, heavy media coverage of transit-related crashes and crimes, and conventional traffic safety messages that emphasize danger rather than safety. Transit agencies can help create a new transit safety narrative by better communicating transit's overall safety and security impacts and providing better guidance concerning how users and communities can enhance transit safety and security.
\end{abstract}

\section{Introduction}

Risk refers to exposure to undesirable events. Some risks, such as standing near a high ledge or facing an angry wild animal, are perceived directly and invoke rational fear. Other risks are less tangible; they are measured statistically and communicated through news media. Inaccurate information about such risks can cause individuals and communities to fear the wrong dangers and make irrational decisions.

This is certainly true of transportation safety (crash) and security (crime) risks. For various reasons discussed in this article, people tend to underestimate automobile travel risks and exaggerate public transit risks. This can be an obstacle to improving transit services and increasing transit use, and, therefore, to achieving strategic planning objectives such as reducing traffic congestion, increasing transportation affordability, and improving mobility options for non-drivers.

This article discusses these issues. It evaluates public transit risks and compares these with automobile risks, examines evidence of unjustified fear of transit, investigates how transportation professionals currently consider these issues, and recommends better ways 
to communicate transit safety impacts. This should be of interest to people involved in transportation, transit, and traffic safety planning.

\section{Evaluating Transportation Risks}

Transportation risk analysis can be challenging because there are various types of risks and ways to measure them. Which risks are considered and how they are evaluated can signifcantly affect analysis results. For example, crash statistics can measure collisions, casualties (human injuries and deaths), or fatalities and may include passengers, vehicle occupants (passengers plus employees), all crash victims (including other road users hit by a transit vehicle), non-collision injuries such as falls that occur in transit vehicles or stations, and employee workplace injuries. Whether or not suicides are included significantly affects rail fatality statistics. Similarly, crime statistics may include violent crimes, all crimes against passengers and employees, or all transit-related crimes, a major portion of which involve trespassing, transit property vandalism, and fare evasion. Risks are considered internal if borne by mode users and external if imposed on other people. Table 1 summarizes these various risk categories. The following sections examine these risks in more detail.

TABLE 1.

Types of Transportation Risks

\begin{tabular}{|l|l|l|}
\hline \multicolumn{1}{|c|}{ Perspectives } & \multicolumn{1}{c|}{ Accidents } & \multicolumn{1}{c|}{ Crime } \\
\hline $\begin{array}{l}\text { Internal } \\
\text { (impacts on a } \\
\text { mode's users) }\end{array}$ & $\begin{array}{l}\text { - Crash damages to vehicle occupants } \\
\text { - Falls (e.g., in a train station) } \\
\text { - Worker injuries }\end{array}$ & $\begin{array}{l}\text { - Crime risk to vehicle occupants } \\
\text { - Crime risk when accessing vehicles } \\
\text { - Terrorist attacks }\end{array}$ \\
\hline $\begin{array}{l}\text { External } \\
\text { (impacts on } \\
\text { non-users) }\end{array}$ & $\begin{array}{l}\text { - Crash risk to other people } \\
\text { (pedestrians, cyclists, occupants of } \\
\text { other vehicles) }\end{array}$ & $\begin{array}{l}\text { - Crime risk that a mode's users } \\
\text { impose on other people (e.g., } \\
\text { criminals who use public transit to } \\
\text { commit crimes) }\end{array}$ \\
\hline
\end{tabular}

\section{Crash Risk}

Public transit has relative low crash rates per unit of travel, as indicated in Table 2. Intercity and commuter passengers have about $1 / 20^{\text {th }}$, urban rail passengers about $1 / 30^{\text {th }}$, and bus passengers about $1 / 60^{\text {th }}$ the traffic fatalities per 100 million passenger-miles as automobile travel. Of course, many factors affect an individual's crash risk, and there are many ways that motorists can increase their safety. For example, drivers can reduce their risks by staying sober and observing speed limits, since about 31 percent of fatal traffic accidents involve an impaired driver and 30 percent involve speeding (NHTSA 2012), but there are still significant risks beyond individual drivers' control, such as errors by other road users and mechanical failures, so even law-abiding motorists face greater crash risks than transit passengers.

TABLE 2.

Passenger Fatalities per Billion Passenger-Miles, 2000-2009

\begin{tabular}{|l|c|}
\hline \multicolumn{1}{|c|}{ Travel Mode } & Deaths per Billion Passenger-Miles \\
\hline Car or light truck driver or passenger & 7.28 \\
\hline Commuter rail and Amtrak & 0.43 \\
\hline Urban mass transit rail (subway or light rail) & 0.24 \\
\hline Bus (transit, intercity, school, charter) & 0.11 \\
\hline Commercial aviation & 0.07 \\
\hline
\end{tabular}

Source: Savage 2013 
Public transit passengers have far lower traffic casualty rates than automobile occupants. Even considering external risk (risks to other road users), transit travel has less than half the total death rate as automobile travel (Figure 1).

FIGURE 1. Transport fatalities

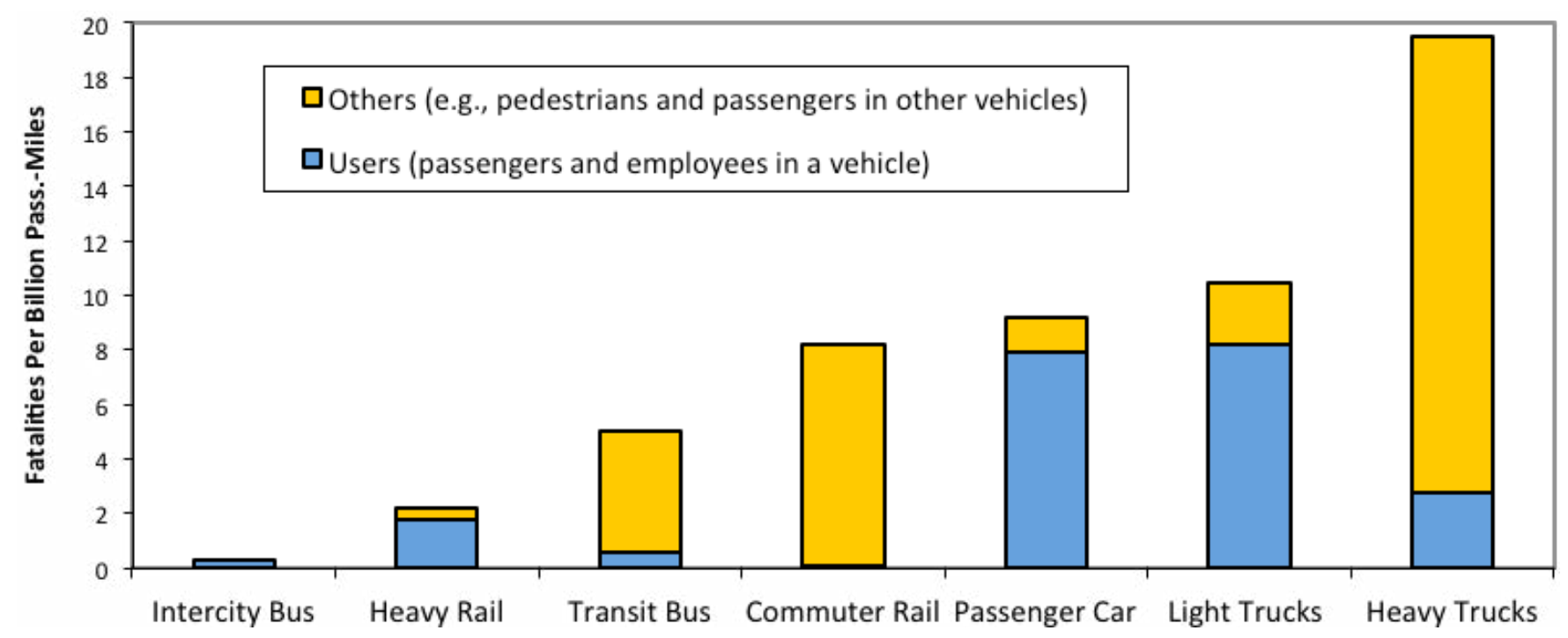

Source: Litman and Fitzroy 2012, based on FHWA and APTA data

Most transit trips include active transport (walking and/or cycling) links, and transit users tend to walk and bike more in total than motorists (Lachapelle et al. 2011). These modes have relatively high per-mile casualty rates, although this risk is largely offset by reduced risks to other travelers and improved public fitness and health, so per capita crashes tend to decline and overall health and longevity increase with more active travel in a community (Rojas-Rueda et al. 2011).

Similarly, as public transit travel increases in a community total (pedestrians, cyclists, motorists and transit passengers), per capita traffic casualty rates tend to decline (Karim, Wahba, and Sayed 2012; Scheiner and Holz-Rau 2011). Various studies using various analysis methods indicate that relatively small transit ridership gains are associated with proportionately larger reductions in per capita crash rates (Duduta et al. 2012). For example, analyzing 29 years of traffic data for 100 U.S. cities, Stimpson et al. (2014) found that a 10 percent increase in the portion of passenger-miles made by transit is associated with 1.5 percent reduction in total traffic deaths. Since only about 2 percent of total person-miles are currently by transit, this means that a 1 percent increase in transit mode share is associated with a 2.75 percent decrease in fatalities per 100,000 residents, which translates into a 5 percent decrease in total traffic fatalities in the 100 cities included in their study. Figure 2 illustrates this relationship. Cities with more than 50 annual transit trips per capita have about half the average traffic fatality rate as regions with less than 20 annual trips per capita. Since Americans average about 1,350 annual person-trips, this represents an increase from about 1.5-4 percent transit mode share. 


\section{FIGURE 2. \\ Traffic fatalities vs. transit trips}

This graph illustrates the relationship between per capita transit ridership and total (including pedestrian, cyclist, automobile occupant, and transit passenger) traffic fatalities for $10 \mathrm{I}$ U.S. cities. As transit travel increases, traffic fatalities tend to decline significantly. Cities with more than 50 annual transit trips per capita have about half the average traffic fatality rate as regions with less than 20 annual trips per capita, indicating that relatively modest increases in transit travel are associated with large traffic safety gains.

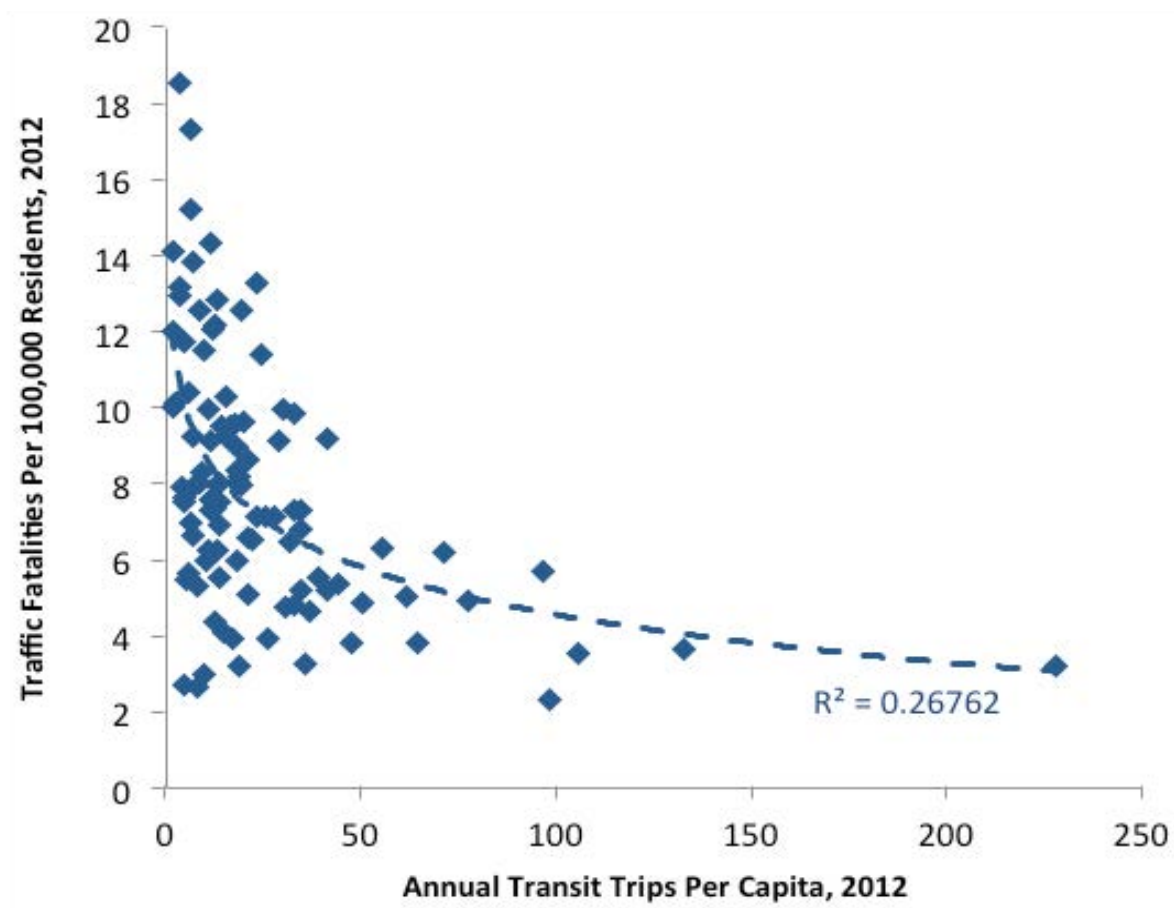

Source: FTA 2012; NHTSA 2012

The U.S. cities with more than 50 annual transit trips per capita include Boston, Chicago, Denver, Honolulu, Los Angeles, New York, Portland, and Seattle. Some smaller cities with just 10-40 annual trips per capita also achieved low traffic fatality rates, including Baltimore, Buffalo, Eugene, Madison, Minneapolis, Pittsburgh, Providence, Rochester, Santa Rosa, Spokane, and Springfield, Massachusetts (NHTSA 2012). These cities all have relatively low per capita vehicle mileage (5,540-9,618 average annual vehicle-miles traveled, compared with 10,036 overall), which helps explain their low crash rates.

Some of these high-transit-ridership, low-VMT cities are compact and transit-oriented because they largely developed prior to the interstate highway era, but some newer cities achieve large transit ridership and traffic safety gains by implementing more recent transit improvements and support strategies. Figure 3 compares transit travel and traffic fatality trends for four cities with pro-transit policies (Denver, Los Angeles, Portland, and Seattle) with four peer cities with more automobile-oriented development policies (Cleveland, Dallas, Houston, and Milwaukee). The pro-transit cities had more than double the transit ridership growth and reduced average traffic fatality rates to nearly half those of the U.S. overall and of the automobile-oriented cities. This suggests that pro-transit policies can increase traffic safety in newer cities. 
(A) Transit Ridership Trends

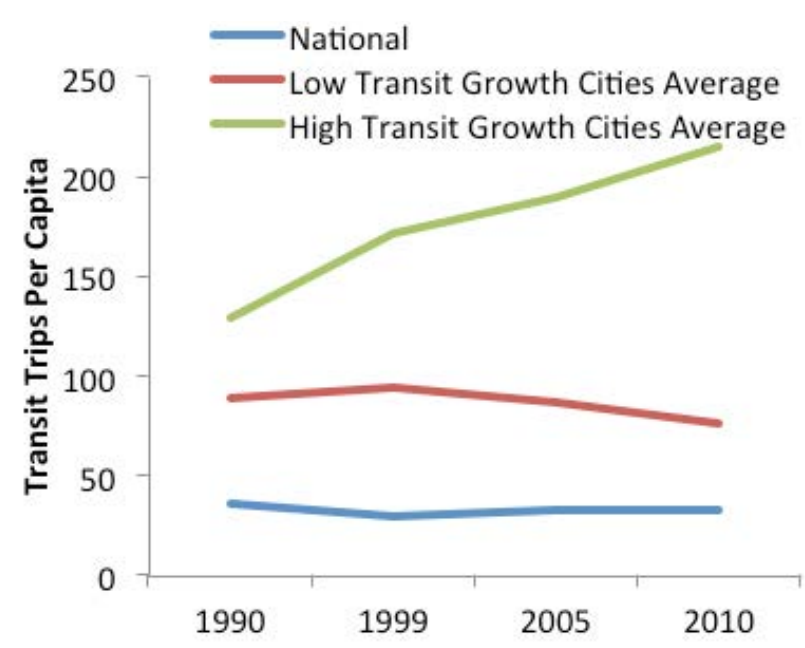

(B) Traffic Fatality Trends

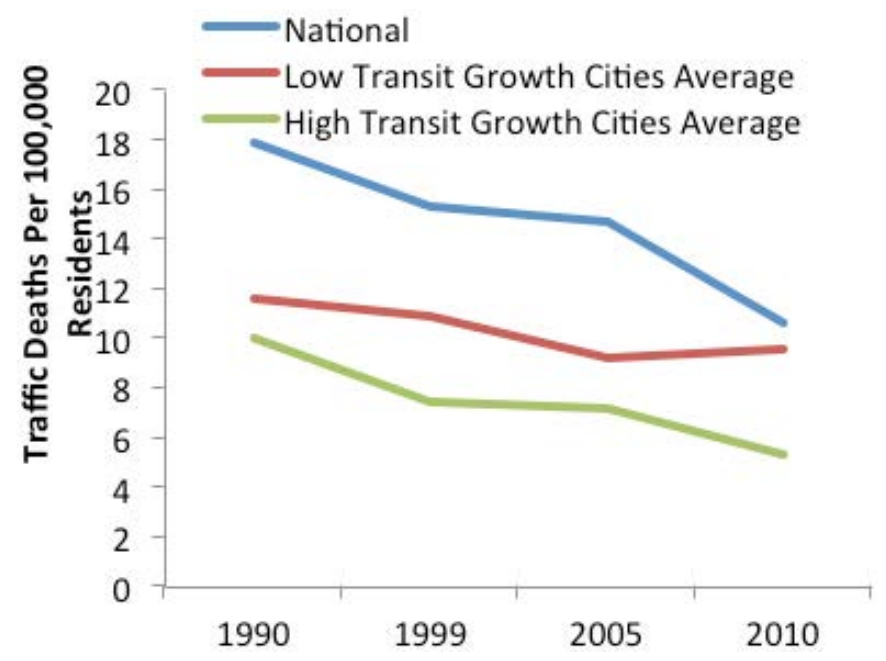

Source: FTA and NHTSA data

FIGURE 3. Trend analysis

The four high-transit-growth cities (Denver, Los Angeles, Portland and Seattle, shown by the green line) achieved far higher transit ridership growth and traffic fatality reductions than the four low-transit-growth cities (Cleveland, Dallas, Houston and Milwaukee, shown by the red line), and national trends (blue line). This suggests that pro-transit policies can significantly reduce traffic fatality rates even in newer, automobile-oriented cities.

Several factors help explain the large crash reductions associated with modest transit ridership increases. Many of the transport system and built environment (urban design) features that tend to increase transit travel also reduce crashes, as summarized in Table 3. Communities that reflect these features are often called new urban, smart growth, or transit-oriented developmen (TOD).

TABLE 3.

Factors That Increase Transit Travel and Traffic Safety

\begin{tabular}{|l|l|}
\hline \multicolumn{1}{|c|}{ Transport System } & \multicolumn{1}{c|}{ Built Environment } \\
\hline - High-quality transit (convenient, comfortable, affordable) service & $\begin{array}{l}\text { - Development density and mix } \\
\text { - Reduced parking supply }\end{array}$ \\
- Good walking and cycling conditions & \\
- Lower traffic speeds & \\
- More connected roadway network & \\
- Transportation demand management & \\
- High fuel taxes, parking fees, and road tolls & \\
\hline
\end{tabular}

Source: Ewing and Dumbaugh 2009

These factors tend to reduce crash rates in several ways. Reducing traffic speeds reduces crash severity. Improving walking and cycling conditions (better sidewalks, crosswalks, bike paths, etc.) reduces pedestrian and cyclist risks, and drivers tend to be more cautious when they see more pedestrians and cyclists (Jacobson 2003). High-quality transit and TOD allow some households to reduce their vehicle ownership_for example, giving up a second car-which leverages additional vehicle travel reductions; as a result, transit-ori- 
ented community residents own about half as many vehicles and generate 40-60 percent fewer vehicle trips as comparable residents of automobile-dependent communities (Arrington and Sloop 2010). More compact, mixed, connected community development tends to reduce traffic speeds and trip distances and increases walking, cycling, and public transit travel (Garrick and Marshall 2011). Together, these factors tend to reduce total vehicle travel and appear to be particularly effective at reducing driving by higher-risk groups including youths, older adults, and alcohol drinkers. Figure 4 illustrates how youth traffic death rates decline with increased transit ridership, which indicates that many young people will reduce their driving if given suitable alternatives.

\begin{abstract}
FIGURE 4.
Youth and total traffic

fatality rates

Youths (aged 15-25 years) tend to have about twice the

traffic fatality rates as the total population average. Both youth and total traffic fatality rates decline significantly with increased transit travel: cities where residents take more than 50 transit trips have about half the average traffic fatality rate as cities where residents average fewer than 20 annual transit trips. The statistical relationship between transit ridership and traffic safety is particularly strong for youths, suggesting that many young people are willing to reduce their higher-risk driving if given suitable alternatives.
\end{abstract}

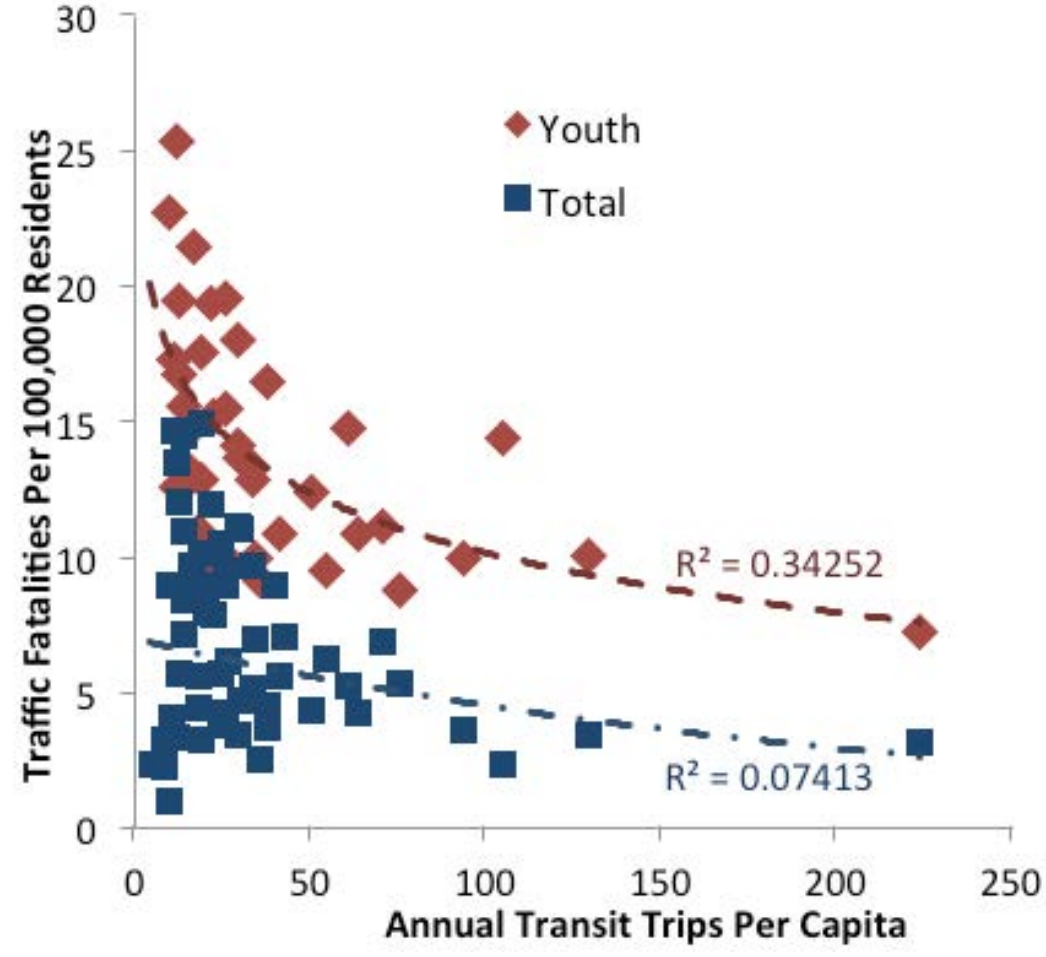

Source: CDC 2012

Similarly, transit service improvements can reduce impaired driving. Residents often drive to parties, restaurants, and bars in automobile-oriented communities, 1 but are more likely to walk or take transit or taxis in transit-oriented communities. Jackson and Owens (2009) and Broyles (2014) found that drunken-driving rates declined after late-night transit service improvements were put into place between entertainment districts and homes. Public transit may also reduce distracted driving; many passengers report that they choose transit in part because they can use telephones, computers, and portable movie players while traveling (Thompson 2010). Many millennials (people born between 1982 and 2003) value having high-quality transit available in part because it allows them to rest, read, and use electronic devices while traveling (APTA 2014).

\footnotetext{
${ }^{1}$ Ironically, bars have among the highest parking requirements of any land use types, indicating that conventional transport planning assumes that it is normal for drinkers to drive and encourages this practice.
} 
As a result, traffic safety policies and programs intended to reduce higher-risk driving, such as graduated licenses, older adult driver testing, and drunk- or distracted-driving discouragement campaigns, become more effective if implemented with appropriate transit improvements. Since most casualty crashes involve multiple vehicles, even responsible drivers who always observe traffic laws and never use transit can benefit from transit improvements that reduce total vehicle traffic and higher-risk driving, and, therefore, their risk of being the victim of other drivers' mistake.

Figure 5 illustrates various ways that pro-transit strategies help increase traffic safety. A particular policy or planning decision may have multiple impacts. For example, a commuter-oriented transit improvement will directly reduce risk to the travelers who shift mode and reduce risk indirectly if this allows some households do reduce their vehicle ownership, which reduces their non-commuter vehicle travel. As a result, various pro-transit policies, including transit service improvements, transportation demand management (TDM) incentives, and support for TOD tend to have cumulative and synergistic effects-implemented together, their impacts are greater than if implemented separately.

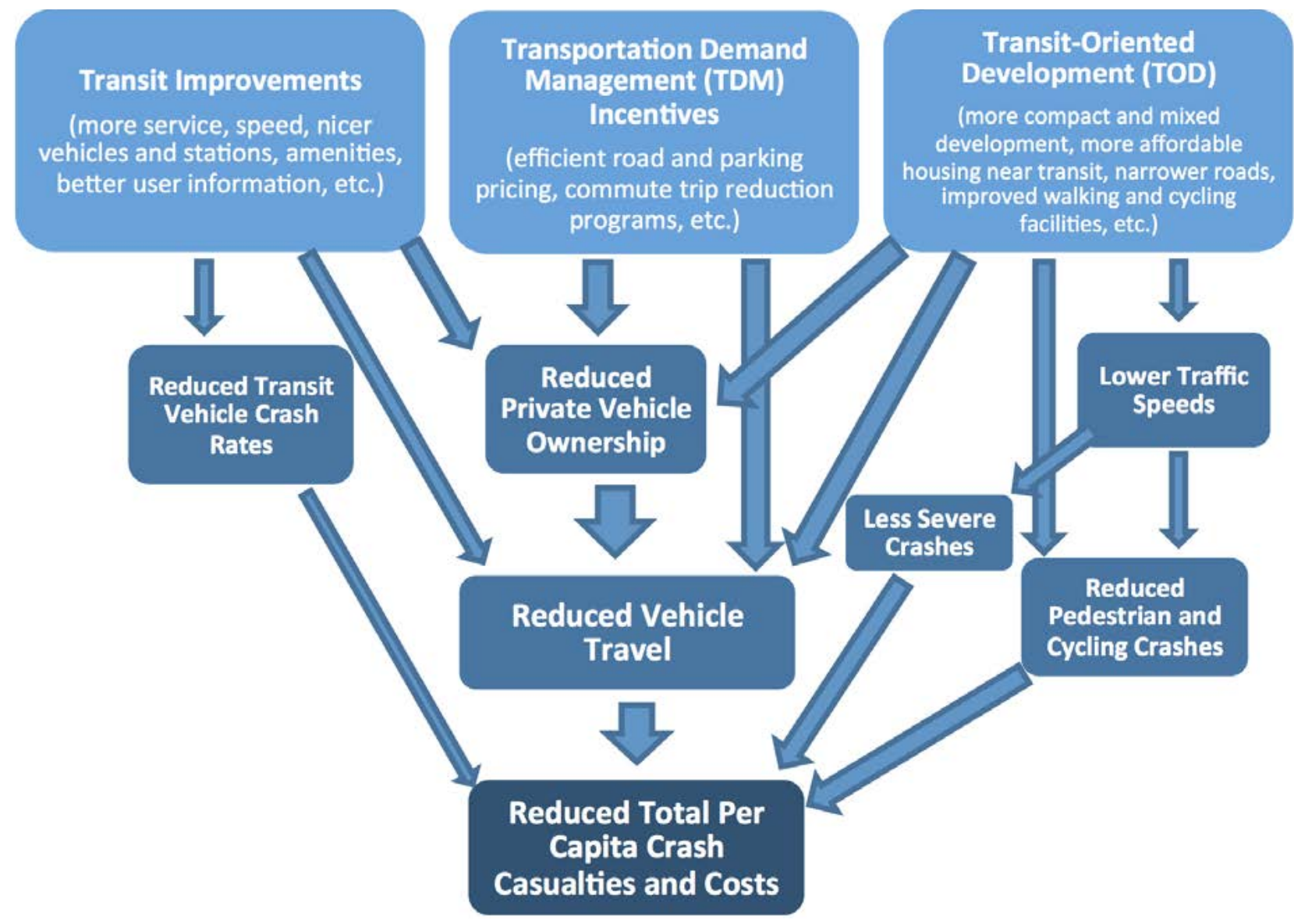

FIGURE 5. Transit improvement and incentives' traffic safety impacts

Public transit service improvements, TDM incentives, and TOD can reduce per capita vehicle travel, both directly and by reducing per capita vehicle ownership, which reduces per capita crashes. These tend to provide significant co-benefits including reduced traffic and parking congestion, consumer savings, energy conservation and emission reductions, and improved mobility for non-drivers. 
It could be said that transit improvements "leverage" safety benefits, that many traffic safety strategies encourage transit use, or that more compact, transit-oriented development increase both transit travel and traffic safety; regardless of how it is described, the result is a significant, positive relationship between pro-transit policies and traffic safety. Ewing and Hamidi (2014) found that each 10 percent increase in their community compactness index is associated with an $\mathbf{1 1 . 5}$ percent increase in transit commute mode share and a 13.8 percent reduction in traffic fatalities. As a result, transit-oriented communities have about one-fifth the per capita traffic fatality rate as automobile-oriented areas, and urban residents have lower overall violent death rates, considering both homicide and traffic risks, than suburban and rural residents (Lucy 2003).

\section{Insecurity (Crime Risk)}

Many people have the impression that public transit travel is dangerous due to high crime risk (DfT 2010; Martin 2011). There is some truth and much inaccuracy in this belief. The truth is that transit serves low-income passengers and communities, and some types of crimes, such as theft and drug crimes, tend to increase with poverty, so there are sometimes positive associations between transit and crime rates. However, this does not mean that transit travel or TODs increase total criminal activity or that transit passengers bear excessive crime risks. On the contrary, crime statistics actually indicate that transit travel has lower overall crime rates than automobile travel, pro-transit policies that increase transit travel by responsible (non-criminal) passengers tend to reduce total crime, and there is much that individuals can do to increase their security.

Comparing transit and automobile crime risks is challenging because they have very different crime risks (Table 4). Transit passengers face personal assault and theft risks, and motorists face risks of road rage, vehicle assault, vehicle theft, and vandalism (AAA 2009; FBI 2012). Transit passengers face risks when walking to and from stations and stops, and motorists face risks walking to and from parked vehicles.

TABLE 4. Transit and Automobile Crime Categories

\begin{tabular}{|l|l|}
\hline \multicolumn{1}{|c|}{ Transit } & \multicolumn{1}{c|}{ Automobile } \\
\hline - Passengers and employee assaults on transit properties & - Road rage and vehicular assault (intentional harm by drivers) \\
- Passengers assaults while accessing transit stations and stops & - Smash-and-grab assaults when vehicles are stopped \\
- Thefts against employees, passengers, and agencies & - Assaults walking to or in parking lots \\
- Transit agency property vandalism & - Thefts of vehicles and from vehicles \\
- Fare evasion & - Vehicle, road and parking facility vandalism \\
\hline
\end{tabular}

Table 5 summarizes reported crimes on transit properties (in vehicles, at stations, and in park-and-ride lots) between 2000 and 2009. Although transit ridership increased 10 percent during this period, violent transit crimes (murder, rape, robbery, and assaults) declined. Trespassing and fare evasion incidents are numerous and increased, so including these categories in analysis gives an exaggerated sense of transit crime rates. Only a tiny portion of total violent crimes occur on transit properties, as indicated in Table 6. 
TABLE 5. Transit Crime Reports

\begin{tabular}{|c|c|c|c|c|c|c|c|c|c|c|}
\hline & 2000 & 2001 & 2002 & 2003 & 2004 & 2005 & 2006 & 2007 & 2008 & 2009 \\
\hline Transit trips (billions) & 9.3 & 9.7 & 9.6 & 9.4 & 9.6 & 9.8 & 10.0 & 10.2 & 10.5 & 10.4 \\
\hline Murder & 12 & 16 & 0 & 4 & 1 & 1 & 2 & 4 & 9 & 9 \\
\hline Forcible rape & 37 & 37 & 65 & 25 & 24 & 23 & 5 & 1 & 4 & 3 \\
\hline Robbery & 3,480 & 3,308 & 1,641 & 1,408 & 1,561 & 1,656 & 2,222 & 2,634 & 2,799 & 2,849 \\
\hline Aggravated assault & 2,217 & 2,286 & 2,560 & 1,638 & 1,330 & 1,332 & 1,768 & 2,066 & 310 & 300 \\
\hline Theft & 13,393 & 13,636 & 12,843 & 8,146 & 7,847 & 6,007 & 6,409 & 7,943 & 8,446 & 9,267 \\
\hline Vehicle theft & 2,112 & 1,909 & 2,117 & 1,800 & 1,584 & 1,361 & 1,051 & 1,756 & 1,442 & 1,008 \\
\hline Arson & 50 & 44 & 23 & 23 & 42 & 27 & 26 & 26 & 0 & 1 \\
\hline Other assaults & 2,799 & 2,441 & 1,589 & 1,752 & 1,546 & 1,530 & 2,141 & 2,266 & 2,748 & 2,702 \\
\hline Vandalism & 7,312 & 2,971 & 1,130 & 953 & 994 & 1,298 & 1,748 & 1,751 & 1,493 & 1,184 \\
\hline Trespassing & 4,303 & 4,597 & 2,278 & 4,126 & 3,162 & 3,220 & 4,503 & 4,919 & 6,402 & 6,296 \\
\hline Fare evasion & 53,863 & 47,258 & 74,385 & 69,950 & 103,156 & 129,590 & 126,092 & 135,602 & 197,819 & 249,004 \\
\hline
\end{tabular}

Source: BTS 2013, Table 2-38

TABLE 6. Transit vs. Total Violent Crimes, 2009

\begin{tabular}{|l|r|r|r|r|}
\hline & Murder & Forcible Rape & Robbery & Aggravated Assault \\
\hline Reported transit crimes & 9 & 3 & 2,849 & 300 \\
\hline Reported total crime & 15,399 & 89,241 & 408,742 & 812,514 \\
\hline Transit to total crime ratios & $1 / 1,711$ & $1 / 29,747$ & $1 / 143$ & $1 / 2,708$ \\
\hline
\end{tabular}

Source: FBI 2012, Table 1

A tiny portion of violent crimes (murders, rapes, robberies, and aggregated assaults) occur on transit properties. Public transit travel has far lower property crime rates than automobile travel (FBI 2012, Table 23). There are about 500 times more crimes against motorists than transit passengers, and, accounting for exposure, transit travel has significantly lower crime rates per passenger trip, mile, and hour (Table 7).

TABLE 7. Automobiles vs. Transit Travel Theft Rates

\begin{tabular}{|l|c|c|c|c|c|c|c|}
\hline \multicolumn{1}{|c|}{ Mode } & Thefts & Pass.-Trips & Rate & Pass.-Miles & Rate & Pass.-Hours & Rate \\
\hline Units & & millions & per M trips & millions & per M miles & millions & per M hrs \\
\hline Transit & 5,959 & 7,520 & 0.8 & 54,393 & 0.1 & 6,071 & 1.0 \\
\hline $\begin{array}{l}\text { Household } \\
\text { vehicles }\end{array}$ & $2,332,604$ & 327,118 & 7.1 & $3,298,168$ & 0.7 & 105,823 & 22.0 \\
\hline
\end{tabular}

Source: FBI and NHTS Data

In addition to being more frequent, automobile property crimes are also more costly. A typical transit passenger theft involves a telephone, wallet, or briefcase worth a few hundred dollars. Automobile theft costs average $\$ 6,019$, more than six times the $\$ 987$ average cost of non-automobile thefts (FBI 2012, Table 23). Total per capita vehicle crime costs tend to be much lower in transit-oriented cities (Roberts and Block 2013). For example, the New 
York City region averages 125 annual vehicle thefts per 100,000 residents, costing about $\$ 8$ annual per capita (assuming $\$ 6,019$ per theft), compared with 476 vehicle thefts per 100,000 residents in automobile-oriented San Bernardino County, costing $\$ 29$ annual per capita.

\section{Urban Crime Rates}

In the past, large cities had relatively high crime rates. However, urban crime rates declined significantly during the last two decades, particularly in the largest cities, as illustrated in Figure 6.

FIGURE 6.

Crime rate trends

Crime rates declined significantly during the last two decades, particularly in cities. Crime rates are now lower in large cities (more than I million residents) than in medium-size cities

(250,000 to I million residents).

FIGURE 7.

Crime rates by community population group

Crime rates tend to increase with city size up to 500,000 residents, but are significantly lower for the largest cities, which also have the highest transit ridership rates (AATPMPC $=$ Average Annual Transit PassengerMiles Per Capita).

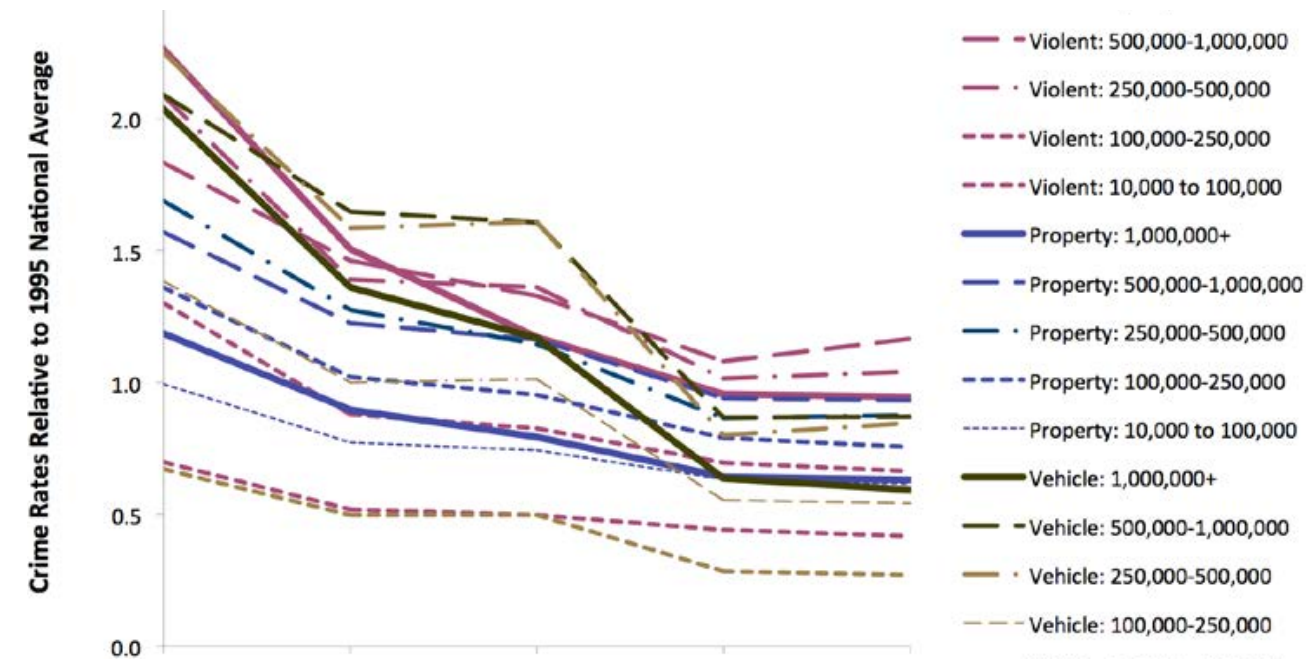

Source: FBI 1995-2012, Table 16

As a result, the largest, most transit-oriented U.S. cities now have significantly lower crime rates than medium-size cities, as illustrated in Figure 7.

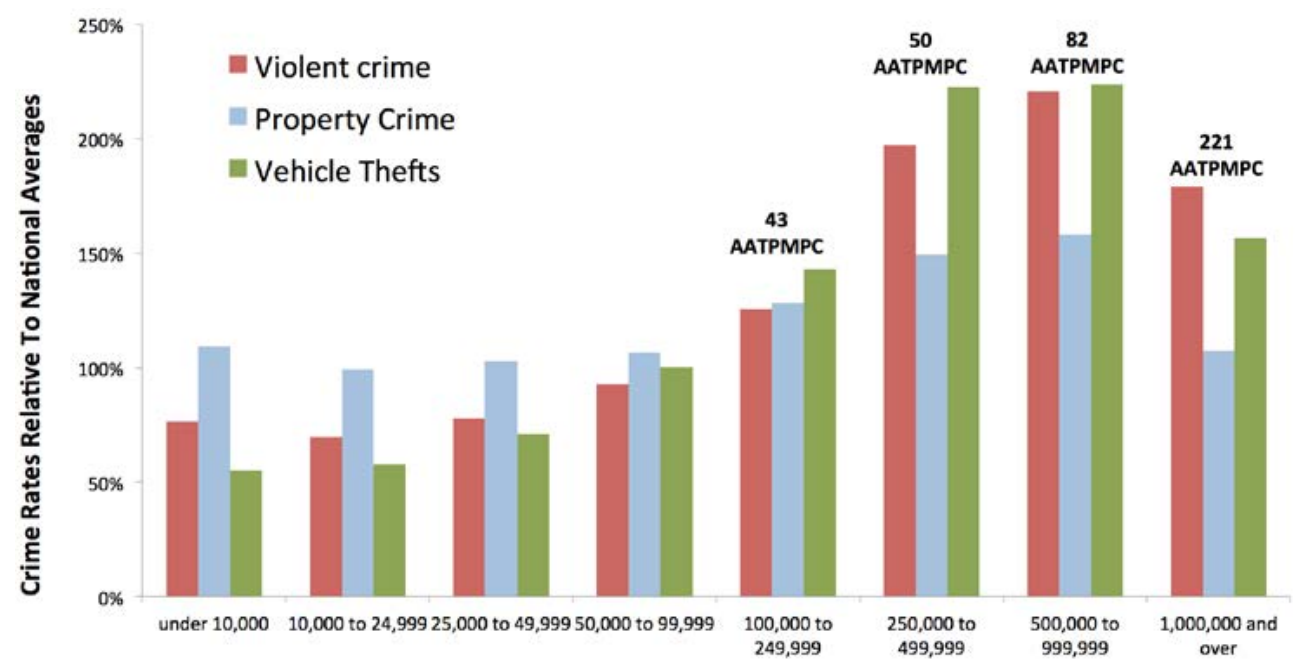

Source: FBI 2012, Table 16 
Residents sometimes oppose new transit lines and stations in their neighborhood based on the fear that this will attract criminals. It is true that transit stations that attract more people and business activity to an area may increase total crimes, but before-and-after studies indicate that crimes per transit passenger, risks to individuals, and total regional crime do not usually increase (Billings, Leland, and Swindell 2011; Blum 2012; Tay et al. 2013). Overall crime rates often decline after high-quality transit service is introduced in a community (Hidalgo et al. 2013).

The following factors help explain why crime rates tend to decline with increased transit travel and more transit-oriented development.

\section{Community Design (Passive Surveillance)}

Crime Prevention Through Environmental Design (CPTED) applies community design strategies to reduce crime risk. There is debate concerning which strategies are most effective. Some experts emphasize defensible space, which assumes that crime risk declines if residents gain more control of an area. This approach is used to justify restrictions on public access including street closures and privatized landscapes (fenced yards, shopping malls, and gated communities) and automobile travel. Others experts emphasize the importance of passive surveillance, also called eyes on the street (Jacobs 1961), which assumes that crime risk declines as more responsible (non-criminal) people live, work, and walk in an area, which tends to justify policies that encourage public access such as well-connected streets and paths, houses and shops close to sidewalks, and walking and cycling encouragement.

Until recently, most CPTED research consisted of before-and-after studies of interventions in high crime areas that indicated that defensible space strategies can reduce crime (Gardiner 1978), but this simply may reflect displacement of crime to other locations. Recent studies that use more comprehensive analysis indicate that crime rates are negatively associated with density and mix (Hillier and Sahbaz 2006; Browning et al. 2010; Christens and Speer 2005; Stucky and Ottensmann 2009). This research indicates that policies that increase walking, cycling, and transit travel and create more compact, mixed TOD tend to reduce total crime.

\section{Increased Economic Opportunity for At-Risk Residents}

Crime is positively associated with poverty. Several studies indicate that public transit improvements and TOD can reduce crime risk by improving economic opportunities and reducing poverty rates for residents who are at risk of criminal activity. Many low-income people cannot drive due to disability, financial, or legal constraints, and those that do often have unreliable vehicles and frequently need alternative mobility options (Gao and Johnston 2009). As a result, it is unsurprising that high-quality transit increases labor participation, particularly by lower-income workers (CTS 2010; Sanchez, Shen, and Peng 2004). Policies that create more compact, multimodal communities tend to increase economic opportunity; for every 10 percent increase in the compact development index, there is a 4.1 percent increase in the probability that a child born to a family in the bottom quintile of the national income distribution reaches the top quintile of the national income distribution by age 30 (Ewing and Hamidi 2014). This suggests that pro-transit policies increase security by reducing root causes of crime: unemployment and poverty. 


\section{Reduced Poverty Concentration}

Crime and delinquency tend to be particularly high and durable (multi-generational) in neighborhoods with concentrated poverty (Fraser, Oakley, and Levy 2013). In response, many government policies are designed to help lower-income urban households relocate to middle-income, suburban neighborhoods, but similar poverty de-concentration and crime reduction benefits can be achieved with mixed-income TOD, which attracts more middle-income households to urban neighborhoods (Basolo 2013; Reconnecting America 2009).

\section{Analysis Summary}

This analysis suggests that public transit travel usually has low crime risk due to surveillance by employees, fellow passengers, and by-passers. The greatest risks occur when passengers walk and wait in isolated areas (Kennedy 2008), but these risks are no greater than what motorists encounter walking to and from isolated parking lots. Transit agencies can reduce crime risks by implementing crime prevention programs and security systems (patrols, cameras, and emergency alarms). Mobile phones increase personal safety by providing immediate access to police, and new apps that provide real-time information on transit vehicle arrival can reduce transit passengers wait times. Travelers can increase security by carrying mobile telephones and avoiding risky situations, for example, by occasionally using a taxi rather than transit to isolated destinations (Loukaitou-Sideris 2009).

Research described in this article indicates that pro-transit policies can help create a positive security cycle as more responsible (non-criminal) people walk, bike, and ride transit in a community, which increases passive surveillance, by improving economic opportunity for at-risk residents and by reducing concentrated poverty, as illustrated in Figure 8 .

FIGURE 8.

Positive security cycle

Communities tend to become safer as more non-criminals walk, bike, and use public transit, and development is more compact and mixed, creating a positive feedback cycle.
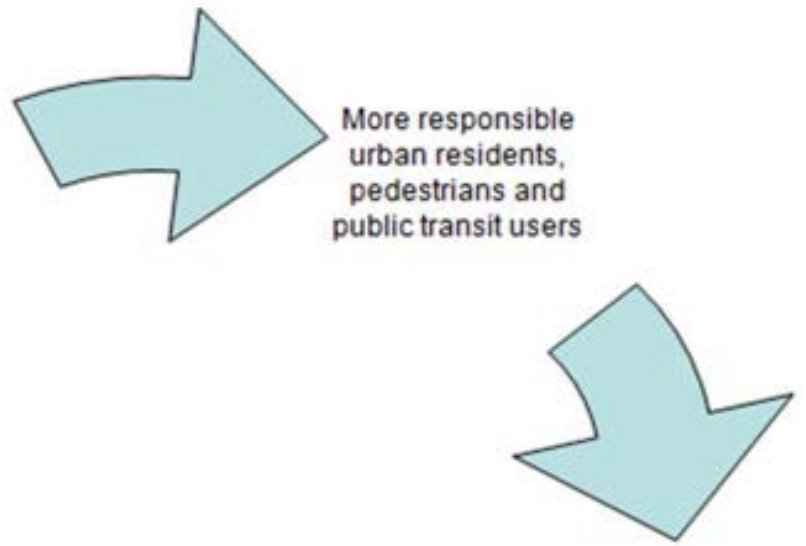

Reduced crime / increased safety

Improved urban services, including better urban transport

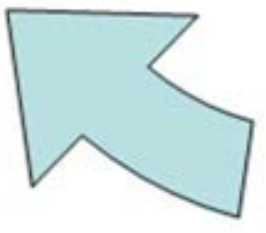

Improved economic opportunity for atrisk residents 


\section{Terrorism Risk}

Another security issue is terrorism risk. Terrorism has become a major concern, although the risk is actually small (Litman 2005; Rabkin et al. 2005). Even including events such as the 2004 Madrid rail bombing, which killed nearly 200 people, and the 2005 London subway attack, which killed about 50 people, traffic crashes kill hundreds of times as many people as terrorism. In 29 Organization for Economic Cooperation and Development (OECD) countries for which data were available, between 1994 and 2003 traffic deaths were approximately 390 times that of international terrorism (Wilson and Thomson 2005). Because traffic accidents are a much greater risk than terrorism, total deaths can increase if terrorism fear causes travelers to shift from transit to automobile (Ayton, Murray, and Hampton 2009; Sivak and Flannagan 2004).

\section{The New Transit Safety Narrative}

Despite its relative safety, many people consider public transit dangerous and are reluctant to use it or support its expansion in their community (Ferrell, Mathur, and Mendoza 2008; Kennedy 2008). Several factors may contribute to this exaggerated fear. Transit travel requires passengers to be confined with strangers in sometimes crowded and uncomfortable vehicles and stations. Although most passengers are responsible, considerate, and clean, a (usually small) portion is anti-social, rude, and dirty. This can cause feelings of powerlessness, discomfort, and insecurity.

Disproportionate media coverage also can stimulate transit fear. Because transit accidents and assaults are infrequent, they tend to receive significant media coverage (Martin 2011). A fatal train or bus crash, or transit terrorism attack, often produces intense national and international media coverage, whereas fatal automobile crashes are so common they are usually reported only locally.

In addition, transit organizations can unintentionally increase fear with safety and security messages that emphasize dangers, including dramatic but unlikely threats such as terrorism, without counterbalancing messages about transit's overall safety, such as those illustrated in Figure 9.

FIGURE 9. Typical transit safety and security messages emphasize risks, not safety
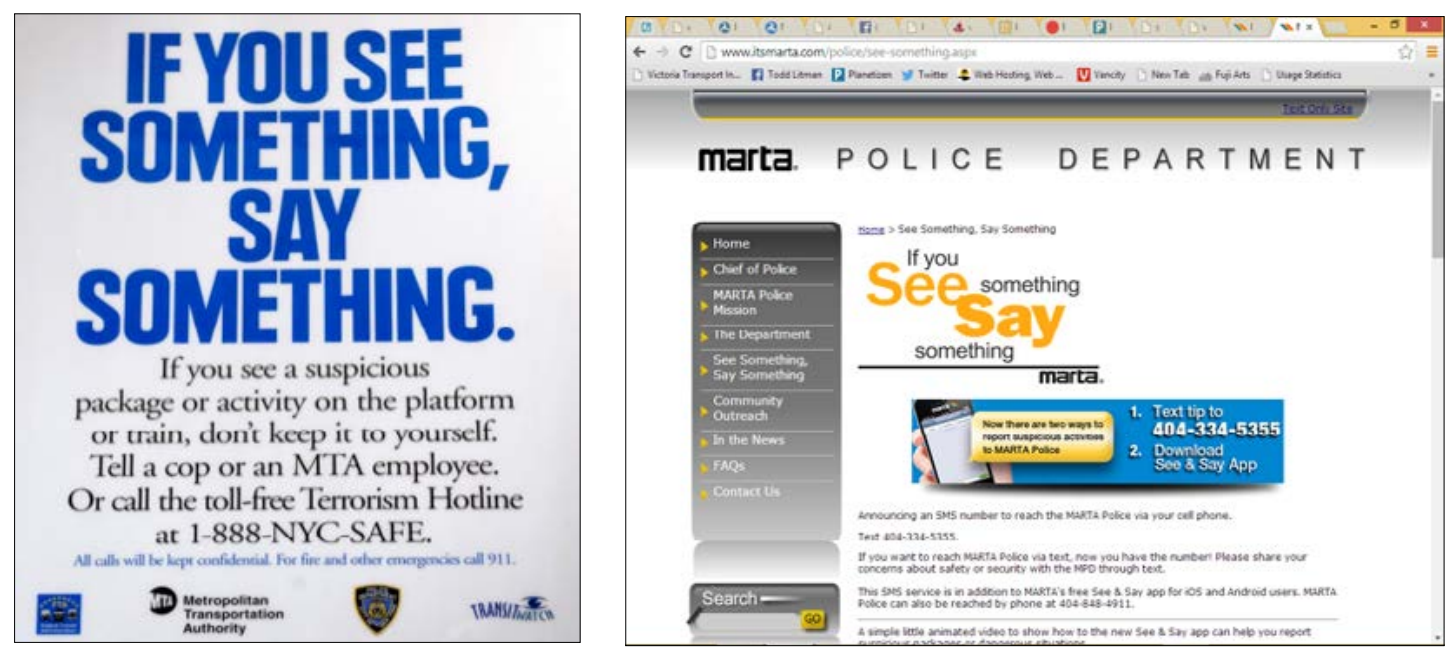
Table 7 summarizes a review of the safety and security messages of 20 representative public transit agency websites. Most describe various risks and safety programs, and some offer safety advice. Although some websites include information about economic and environmental benefits, only one (Utah) mentions the overall safety of transit travel, and none describe transit's relatively low crime rates.

TABLE 7. Summary of Transit Agency Websites' Safety and Security Messages

\begin{tabular}{|c|c|}
\hline Agency, City (Website) & Safety and Security Messages \\
\hline $\begin{array}{l}\text { Champaign-Urbana Mass Transit District, Champaign-Urbana, } \\
\text { IL (www.cumtd.com) }\end{array}$ & $\begin{array}{l}\text { "Safety and Security" page describes what agency is doing to maximize rider } \\
\text { security and safety. }\end{array}$ \\
\hline $\begin{array}{l}\text { Chattanooga Area Regional Transportation Authority, } \\
\text { Chattanooga, TN (www.carta-bus.org) }\end{array}$ & No mention of safety or security. \\
\hline Chicago Transit Authority, IL (www.transitchicago.com) & Includes "Safety and Security" page and "Security Tips" brochure. \\
\hline $\begin{array}{l}\text { Greater New Haven Transit District, New Haven, CT } \\
\text { (www.gnhtd.org) }\end{array}$ & $\begin{array}{l}\text { Emphasizes that operators receive special safety training. No other discussion } \\
\text { of safety or security. }\end{array}$ \\
\hline Intercity Transit, Olympia, WA (www.intercitytransit.com) & $\begin{array}{l}\text { Lists various benefits of public transit, but not traffic safety. Has no specific } \\
\text { safety or security messages }\end{array}$ \\
\hline Long Beach Transit, CA (www.lbtransit.com) & "Safety and Security" page describes agency's security programs. \\
\hline $\begin{array}{l}\text { Maryland Transit Administration, Baltimore, MD } \\
\text { (www.mta.maryland.gov) }\end{array}$ & $\begin{array}{l}\text { "MTA Police Force" page describes policing programs. "Safety, Quality } \\
\text { Assurance, Risk Management" page describes some safety programs. }\end{array}$ \\
\hline $\begin{array}{l}\text { Massachusetts Bay Transportation Authority, Boston, MA } \\
\text { (www.mbta.com) }\end{array}$ & $\begin{array}{l}\text { "Safety" page describes ways to increase user safety (mostly personal } \\
\text { security). "Transit Police" page describes security programs and recent crimes. }\end{array}$ \\
\hline Metro Transit, Minneapolis, MN (www.metrotransit.org) & $\begin{array}{l}\text { Includes "Safety and Security" page that describes safety and policing } \\
\text { programs and offers safety tips. }\end{array}$ \\
\hline METRO, Oklahoma City, OK (www.gometro.org) & $\begin{array}{l}\text { "Transit Benefits" page mentions "enhances safety" as a community benefit. } \\
\text { "Safety and Security" page provides safety and security tips. }\end{array}$ \\
\hline $\begin{array}{l}\text { Metropolitan Atlanta Rapid Transit Authority, Atlanta, GA } \\
\text { (www.itsmarta.com) }\end{array}$ & $\begin{array}{l}\text { "Safety on MARTA" page offers safety and security trip, "MARTA Police" page } \\
\text { describes agency's policing services. }\end{array}$ \\
\hline $\begin{array}{l}\text { Metropolitan Transit Authority of Harris County, Houston, TX } \\
\text { (www.ridemetro.org) }\end{array}$ & $\begin{array}{l}\text { "Safety and Security" page describes ways to increase personal safety and } \\
\text { security, states that "In today's world, protecting one's personal safety has } \\
\text { never been more important." }\end{array}$ \\
\hline $\begin{array}{l}\text { Metropolitan Transportation Authority, New York, NY } \\
\text { (http://new.mta.info) }\end{array}$ & $\begin{array}{l}\text { "Customer Safety" page offers safety tips. "MTA Police” page describes police } \\
\text { services. "Performance Indicators" page reports accident rates. }\end{array}$ \\
\hline Miami-Dade Transit, Miami, FL (www.miamidade.gov) & $\begin{array}{l}\text { "Passenger Safety" page provides safety tips. "Transit Watch" page encourages } \\
\text { passengers to report suspicious and illegal activity. }\end{array}$ \\
\hline Pierce Transit, WA (www.piercetransit.org) & "Safety and Security" page emphasizes responsible rider behavior. \\
\hline $\begin{array}{l}\text { Southeastern Pennsylvania Transportation Authority, } \\
\text { Philadelphia, PA (www.septa.org) }\end{array}$ & $\begin{array}{l}\text { "Safety and Security" page emphasizes anti-terrorism programs, describes } \\
\text { policing activities, offers various safety and security tips. }\end{array}$ \\
\hline $\begin{array}{l}\text { Suburban Mobility Authority for Regional Transportation, } \\
\text { Detroit, MI (www.smartbus.org) }\end{array}$ & $\begin{array}{l}\text { "Safety and Security" page provides basic safety advice, emphasizes operators' } \\
\text { safety training and system's low accident rates. }\end{array}$ \\
\hline $\begin{array}{l}\text { Toronto Transit Commission, Toronto, ON } \\
\text { (www.itsmarta.com) }\end{array}$ & $\begin{array}{l}\text { "Safety and Security" page offers information and guidance on public transit } \\
\text { safety and security. }\end{array}$ \\
\hline TransLink, Vancouver, BC (www.translink.ca) & $\begin{array}{l}\text { "Sustainability" page highlights environmental benefits but not safety. "Safety } \\
\text { and Security" page describes agency's safety and security programs. }\end{array}$ \\
\hline Utah Transit Authority, Salt Lake City, UT (www.rideuta.com) & $\begin{array}{l}\text { "Transit Studies" page states, "You are } 25 \text { times less likely to die in a traffic } \\
\text { accident when you ride public transit versus travel in a personal vehicle." } \\
\text { "Safety and Security" page offers safety tips. }\end{array}$ \\
\hline
\end{tabular}


Transit agencies websites seldom provide positive information about public transit safety benefits. Conventional traffic safety programs and information resources, such as those produced by the National Highway Traffic Safety Administration (NHTSA 2013) and the Toward Zero Deaths program (TZD 2011), tend to ignore public transit as a traffic safety strategy. ${ }^{2}$ The conventional traffic safety narrative emphasizes that, because most crashes can be blamed on special risks such as impaired driving or speeding, and modern vehicles have occupant protection features such as seatbelts and airbags, a responsible driver in a modern vehicle is very safe. As a result, conventional traffic safety programs emphasize targeted strategies that reduce youth, older adult, impaired, and distracted driving. From this perspective, efforts to increase safety by reducing overall vehicle travel are inefficient and unfair since they "punish" all drivers for the problems created by an irresponsible minority. This approach is understandable, since most traffic safety programs are sponsored by highway agencies and the automobile industry, and few safety experts are familiar with transit planning or transportation demand management.

Conventional traffic safety analysis tends to evaluate risks using distance-based units such as fatalities per 100 million vehicle-miles. Measured this way, traffic fatality rates declined more than two-thirds during the last half century (red line in Figure 10). From this perspective, traffic safety programs were effective and should be continued. However, per-capita vehicle travel increased significantly during that period, offsetting much of the decline in per-mile casualty rates. When measured per capita, as with other health risks (blue line in Figure 10), there was little improvement despite major investments in road and vehicle safety, and traffic safety programs. Much larger safety gains could be expected. For example, seat belt use increased from about zero percent in 1960 to 75 percent in 2002, which alone should have reduced traffic fatalities about 33 percent (seat belt use reduces crash fatality risk about 45\%); yet, per-capita deaths declined just 25 percent. The U.S. has the highest per-capita traffic fatality rate of all OECD countries, an outcome that can be explained by the fact that Americans have the highest per-capita annual vehicle mileage of its peers. Evaluated this way, conventional traffic safety programs seem less effective, and new strategies should be considered.

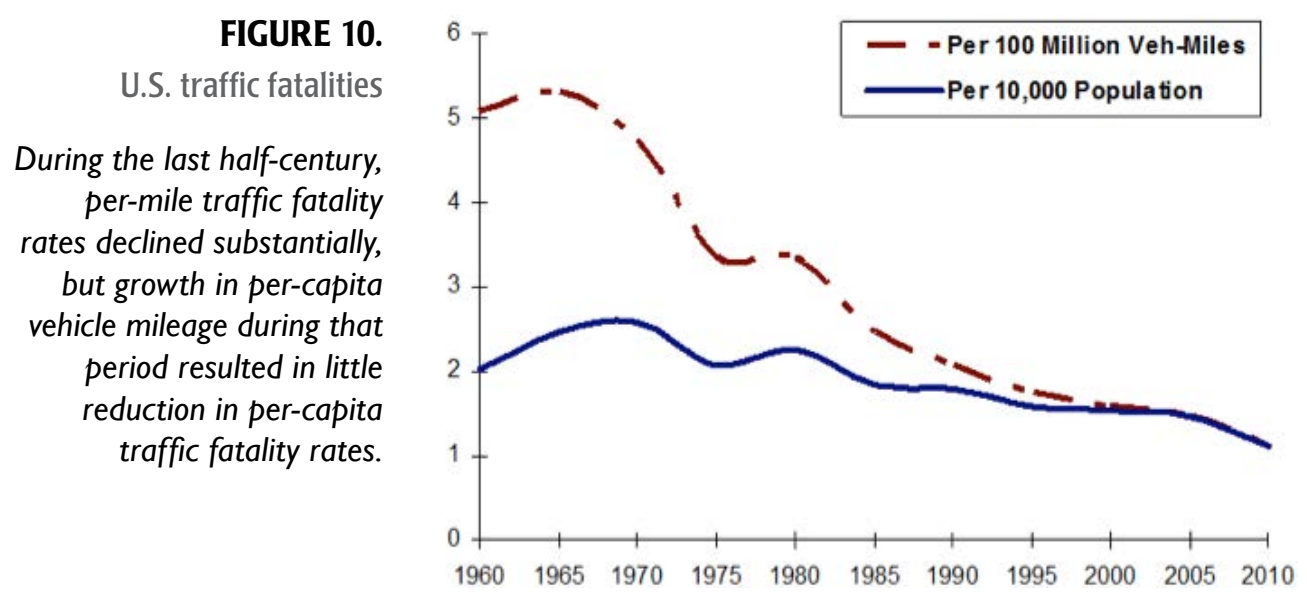

Source: Traffic Safety Facts, NHTSA 2014

${ }^{2}$ An exception is the Federal Highway Administration's Transportation Planner's Safety Desk Reference (FHWA 2010), which recognizes public transit encouragement and transportation demand management as potential traffic safety strategies. 
This has important implications for transit safety impact analysis. Evaluating traffic risk using distance-based units ignores the additional crashes caused by increases in per capita vehicle travel and the safety benefits of vehicle travel reduction strategies. When evaluated per capita, as with other health risks, the full potential safety benefits of pro-transit policies become evident.

Transportation professionals can help create a more accurate and positive narrative about public transit safety and security. This new narrative recognizes that safety and security are serious concerns, emphasizes that public transit is overall very safe and that risks tend to decline as transit travel increases, addresses common misperceptions about transit risks, and provides practical guidance for passengers and communities to further reduce risks. Table 8 summarizes key conclusions about actual and perceived transit risks and how they can be addressed in a new narrative.

TABLE 8. Actual and Perceived Transit Risks

\begin{tabular}{|c|c|c|c|}
\hline Type of Risk & Actual Magnitude & Perceived Magnitude & New Narrative \\
\hline $\begin{array}{l}\text { Transit passenger } \\
\text { crash risk }\end{array}$ & $\begin{array}{l}\text { Very low. Order-of-magnitude lower than } \\
\text { automobile travel. }\end{array}$ & $\begin{array}{l}\text { Although infrequent, transit crashes } \\
\text { receive heavy media coverage, which } \\
\text { exacerbates fear. }\end{array}$ & $\begin{array}{l}\text { Emphasize overall safety of transit } \\
\text { travel and ways to further increase } \\
\text { this safety. }\end{array}$ \\
\hline $\begin{array}{l}\text { Crash risk while } \\
\text { accessing transit }\end{array}$ & $\begin{array}{l}\text { Walking and cycling have relatively high } \\
\text { crash rates per mile/km, but per-capita } \\
\text { crashes tend to decline with increased } \\
\text { use of these modes. }\end{array}$ & $\begin{array}{l}\text { Pedestrian and cyclist crash injuries } \\
\text { tend to receive heavy media } \\
\text { attention. }\end{array}$ & $\begin{array}{l}\text { Acknowledge this risk and describe } \\
\text { practical ways that individuals and } \\
\text { communities can reduce it. }\end{array}$ \\
\hline $\begin{array}{l}\text { Crash risk to other } \\
\text { road users }\end{array}$ & $\begin{array}{l}\text { Moderate. Risk to other road users } \\
\text { declines as transit mode share increases. }\end{array}$ & $\begin{array}{l}\text { Transit vehicle crashes receive heavy } \\
\text { media coverage, which exacerbates } \\
\text { fear. }\end{array}$ & $\begin{array}{l}\text { Communicate transit's relative } \\
\text { safety to other road users and ways } \\
\text { to reduce these risks. }\end{array}$ \\
\hline $\begin{array}{l}\text { Overall community } \\
\text { crash rates }\end{array}$ & $\begin{array}{l}\text { Decline with increased transit mode } \\
\text { share and very low in TODs. }\end{array}$ & $\begin{array}{l}\text { Impact is seldom considered in } \\
\text { media coverage or planning analysis. }\end{array}$ & $\begin{array}{l}\text { Communicate safety of TOD and } \\
\text { quantify for planning analysis. }\end{array}$ \\
\hline $\begin{array}{l}\text { Transit passenger } \\
\text { crime risk }\end{array}$ & Crime rates are low on transit properties. & $\begin{array}{l}\text { Transit crimes often receive } \\
\text { heavy media coverage, leading to } \\
\text { exaggerated fear. }\end{array}$ & $\begin{array}{l}\text { Communicate relative security of } \\
\text { transit and practical ways to reduce } \\
\text { risk. }\end{array}$ \\
\hline $\begin{array}{l}\text { Crime risk while } \\
\text { accessing transit }\end{array}$ & $\begin{array}{l}\text { Variable. Usually low due to passive } \\
\text { surveillance, but may be significant in } \\
\text { isolated areas. }\end{array}$ & Perceived as very dangerous. & $\begin{array}{l}\text { Communicate relative security of } \\
\text { transit and practical ways to reduce } \\
\text { risks. }\end{array}$ \\
\hline $\begin{array}{l}\text { Overall community } \\
\text { crime rates }\end{array}$ & $\begin{array}{l}\text { Transit improvements can reduce total } \\
\text { crime by increasing passive surveillance } \\
\text { and economic opportunity for at-risk } \\
\text { residents. }\end{array}$ & $\begin{array}{l}\text { Many people have excessive fear of } \\
\text { large, dense cities based on outdated } \\
\text { information. }\end{array}$ & $\begin{array}{l}\text { Communicate relative security of } \\
\text { transit-oriented communities and } \\
\text { practical ways to further reduce } \\
\text { risks. }\end{array}$ \\
\hline Terrorism risk & $\begin{array}{l}\text { Low. Even during periods of high terrorist } \\
\text { activity, total casualties are relatively low. }\end{array}$ & $\begin{array}{l}\text { Transit agencies devote considerable } \\
\text { attention to this risk. }\end{array}$ & $\begin{array}{l}\text { Emphasize that this risk is small, } \\
\text { identify practical ways to reduce it. }\end{array}$ \\
\hline
\end{tabular}

\section{Conclusions}

Public transit is overall very safe (low crash rate) and secure (low crime rate). Transit travel has less than one-tenth the crash casualty rate as automobile travel, and TOD residents have less than one-fifth the per-capita traffic casualty rate as in automobile-oriented communities. Transit crimes tend to be less frequent and costly overall than motor vehicle crimes. Pro-transit policies can significantly increase overall traffic safety and community security. 
Despite these benefits, many people fear transit, experts seldom promote transit as a traffic safety strategy, and transit advocates seldom emphasize safety as significant benefit of pro-transit policies. Various factors contribute to the under-appreciation of transit safety benefits, including the nature of transit travel, dramatic news coverage of transit crashes and crimes, transit agency messages that unintentionally emphasize risks without providing information on its overall safety, and biased traffic safety analysis.

Despite these obstacles, there is significant potential for changing perceptions. We now have credible evidence that public transit is relatively safe and secure, and pro-transit policies can further reduce risks. Planning is becoming more multimodal, and there is increasing recognition that pro-transit policies are justified to achieve various planning objectives. There is growing demand for transit travel and TOD. A few traffic safety programs already recognize the safety benefits of pro-transit policies, which suggests that many people may be receptive to new messages about transit safety benefits.

Transportation professionals can create a new, more accurate and positive transit safety narrative that emphasizes the overall safety of transit travel and TOD, communicates the safety impacts of pro-transit policies, addresses common misperceptions about transit risks, and provides practical guidance on how to further reduce transit risks. Although rational arguments alone may not change everybody's beliefs about transit safety, such information should be part of overall marketing programs that help reposition transit as an efficient, attractive, enjoyable and prestigious form of travel that benefits people and communities.

The following are recommendations for the new transit safety narrative:

- Provide information that highlights the overall safety and security of public transit travel and transit-oriented communities, and how pro-transit policies tend to reduce overall risks. Integrate this information into all transit organization communications and planning activities.

- Identify and correct common misconceptions about transit safety and security.

- Collect and distribute transportation crash and crime data, which allows transit and automobile risks to be compared and tracked over time.

- Encourage traffic safety experts to recognize public transit safety impacts and consider pro-transit policies as potential traffic safety strategies. Develop models that predict the safety benefits of specific pro-transit policies.

- Provide practical guidance to transit passengers and communities on ways to increase their safety and security-for example, how they should respond if they see dangerous or inappropriate activity.

- Create multi-dimensional safety and security programs that integrate local planning, infrastructure design, neighborhood policing, and user information to increase transit user and community safety.

- Incorporate public transit safety benefits into transport project economic evaluation. Treat increased safety as a benefit when evaluating transit improvements, encouragement programs, and transit-oriented developments. 


\section{References}

AAA. 2009. Aggressive driving: Research update, American Automobile Association Foundation for Traffic Safety, www.aaafoundation.org/sites/default/files/AggressiveDrivingResearchUpdate2009.pdf.

Arrington, G. B., and Kimi Iboshi Sloop. 2010. New Transit Cooperative Research Program Research Confirms Transit-Oriented Developments Produce Fewer Auto Trips, ITE Journal 79(6): 26-29.

APTA. 2014. Millennials \& mobility: The millennial mindset. American Public Transit Association, www.apta.com/resources/reportsandpublications/Documents/APTA-Millennials-and-Mobility.pdf.

Ayton, Peter, Samantha Murray, and James Hampton. 2009. Terrorism, dread risk, and bicycle accidents. Presented at the Society for Judgment and Decision Making Annual Meeting, November 2009, Boston, MA, www.sjdm.org/programs/2009-posters.pdf; described in Casualty toll of the dread risk effect, Medical News Today, 3 Sept 200, at www.medicalnewstoday.com/articles/162812.php.

Billings, Stephen B., Suzanne Leland, and David Swindell. 2011. The effects of the announcement and opening of light rail transit stations on neighborhood crime. Journal of Urban Affairs 33(5): 549-566, December 2011; summary at http://onlinelibrary. wiley.com/doi/10.1111/j.1467-9906.2011.00564.x/abstract.

Blum, Alex. 2012. New MAX line might not be the "crime express. Portland Tribune, August 1, 2012, http://tinyurl.com/ct22q46.

Browning, Christopher R., et al. 2010. Commercial density, residential concentration, and crime: Land use patterns and violence in neighborhood context. Journal of Research in Crime and Delinquency 47(3): 329-357, http://jrc.sagepub.com/content/47/3/329. short.

Broyles, Joshua.2014. Drinking and driving and public transportation: A test of the routine activity framework, Master's thesis, Arizona State University, http://repository.asu. edu/attachments/135054/content/Broyles_asu_0010N_13784.pdf.

BTS (2013), National transportation statistics, Bureau of Transportation Statistics, www. rita.dot.gov/bts/sites/rita.dot.gov.bts/files/NTS_Entire_13Q3.pdf.

Christens, Brian, and Paul W. Speer. 2005. Predicting violent crime using urban and suburban densities, Behavior and Social Issues 14: 113-127, http://journals.uic.edu/ojs/index. php/bsi/article/view/334.

CTS. 2010. How light-rail transit improves job access for low-wage workers: A Transitway Impacts Research Program (TIRP) research brief, Center for Transportation Studies, University of Minnesota, www.cts.umn.edu/Research/featured/transitways/research.

DfT. 2010. Crime and public transport. UK Department for Transport, www.dft.gov.uk/ pgr/crime. 
Duduta, Nicolae, Claudia Adriazola, Carsten Wass, Dario Hidalgo, and Luis Antonio Lindau. 2012. Traffic safety on bus corridors: Guidelines for integrating pedestrian and traffic safety into the planning, design, and operation of BRT, busways and bus lanes. EMBARQ, http://tinyurl.com/lg2cdk6.

Ewing, Reid, and Eric Dumbaugh. 2009. The built environment and traffic safety: A review of empirical evidence. Journal of Planning Literature 23(4), May: 347-367, http:// tinyurl.com/pkf4y63.

Ewing, Reid, and Shima Hamidi. 2014. Measuring urban sprawl and validating sprawl measures. Metropolitan Research Center, University of Utah for the National Cancer Institute, the Brookings Institution and Smart Growth America, www.arch.utah.edu/ cgi-bin/wordpress-metroresearch.

Federal Bureau of Investigation. 2012. Crime in the United States 2012. Uniform Crime Statistics, www.fbi.gov/about-us/cjis/ucr/crime-in-the-u.s/2012, Tables 12-19.

Ferrell, Christopher, Shishir Mathur, and Emilia Mendoza. 2008. Neighborhood crime and travel behavior: An investigation of the influence of neighborhood crime rates on mode choice. Report 07-02, Mineta Transportation Institute, http://works.bepress. com/shishirmathur/12.

Federal Highway Administration (FHWA). 2010. Transportation planner's safety desk reference, http://tsp.trb.org/assets/FR1_SafetyDeskReference_FINAL.pdf.

Fraser, James C., Deirdre Oakley, and Diane K. Levy. 2013. Mixed messages on mixed income. Cityscape 15(2), www.huduser.org/portal/publications/Cityscape_Jul2013. pdf.

Federal Transit Administration. National Transit Database, www.ntdprogram.gov/ntdprogram.

Gao, Shengyi, and Robert A. Johnston. 2009. Public vs. private mobility for low income households: Transit improvements vs. increased car ownership in the Sacramento region. Transportation Research Record 2125: 9-15.

Gardiner, Richard A. 1978. Design for safe neighborhoods: The environmental security planning and design process. National Institute of Law Enforcement and Criminal Justice of the U.S. Department of Justice and from the U.S. Department of Housing and Urban Development, https://www.ncjrs.gov/pdffiles1/Digitization/50335NCJRS.pdf.

Hidalgo, Darío, Liliana Pereira, Nicolás Estupiñán, and Pedro Luis Jiménez. 2013. TransMilenio BRT system in Bogota: High performance and positive impact - Main results of an ex-post evaluation, Research in Transportation Economics 39(1), March: 133-138, www.sciencedirect.com/science/article/pii/S0739885912000777.

Hillier, Bill, and Ozlem Sahbaz. 2006. High-resolution analysis of crime patterns in urban street networks: An initial statistical sketch from an ongoing study of a London borough. University College London, www.spacesyntax.tudelft.nl/media/Long\%20 papers\%20l/hilliersahbaz.pdf. 
Institute of Transportation Engineers (ITE). 2007. Desktop reference for crash reduction factors, www.ite.org/safety/issuebriefs/Desktop\%20Reference\%20Complete.pdf.

Jackson, C. Kirabo, and Emily Greene Owens. 2009. One for the road: Public transportation, alcohol consumption, and intoxicated driving. IZA Conference, www.iza.org/ conference_files/riskonomics2009/owens_e4815.pdf.

Jacobs, Jane. 1961. The Death and Life of Great American Cities. Modern Library.

Jacobsen, Peter L. 2003. Safety in numbers: More walkers and bicyclists, safer walking and bicycling. Injury Prevention 9: 205-209, http://injuryprevention.bmj.com/cgi/content/ full/9/3/205.

Karim, Md Ahsanul, Mohamed M. Wahba, and Tarek Sayed. 2012. Evaluating the safety estimates of transit operations and city transportation plans. Transportation Research Board Annual Meeting, http://amonline.trb.org/1slsr0/1slsr0/1.

Kennedy, D. M. 2008. Personal security in public transport travel In New Zealand: Problems, issues \& solutions, Report 344, Land Transport New Zealand, www.nzta.govt. $\mathrm{nz} /$ resources/research/reports/344.

Lachapelle, Ugo, et al. 2011. Commuting by public transit and physical activity: Where you live, where you work, and how you get there. Journal of Physical Activity and Health 8(1): S72-S82, http://tinyurl.com/qa3knzu.

Litman, Todd. 2005. Terrorism, transit and public safety: Evaluating the risks. Journal of Public Transportation 8(4): 33-46, www.nctr.usf.edu/jpt/journal.htm.

Litman, Todd. 2012. Evaluating public transit benefits and costs. VTPI, www.vtpi.org/ tranben.pdf.

Litman, Todd, and Steven Fitzroy. 2012. Safe travels: Evaluating mobility management traffic safety impacts. VTPI, www.vtpi.org/safetrav.pdf.

Loukaitou-Sideris, Anastasia. 2009. How to ease women's fear of transportation environments: Case studies and best practices. Mineta Transportation Institute, http:// transweb.sjsu.edu/project/2611.html.

Lucy, William H. 2003. Mortality risk associated with leaving home: Recognizing the relevance of the built environment. American Journal of Public Health 93(9), September: 1564-1569, www.ajph.org/cgi/content/full/93/9/1564.

Marshall, Wesley E., and Norman W. Garrick. 2011. Evidence on why bike-friendly cities are safer for all road users. Environmental Practice 13(1), March, http://files.meetup. com/1468133/Evidence\%20on\%20Why\%20Bike-Friendly.pdf.

Martin, John Martin. 2011. The incidence and fear of transit crime: A review of the literature. Centre for Public Safety, University of the Fraser Valley, http://tinyurl.com/ pxrtt3h.

Myers, Sage R., et al. 2013. Safety in numbers: Are major cities the safest places in the United States? Annals of Emergency Medicine 62(4): 408-418.e3, www.annemergmed. com/webfiles/images/journals/ymem/FA-5548.pdf. 
National Highway Traffic Safety Administration (NHTSA). Traffic safety facts, www-nrd. nhtsa.dot.gov/CMSWeb/listpublications.aspx.

NHTSA. 2013. Countermeasures that work: A highway safety countermeasure guide for state highway safety offices, www.nhtsa.gov/Driving+Safety/Research+\&+Evaluation.

Organization for Economic Cooperation and Development (OECD). 2012. International road traffic and accident database, www.bast.de/htdocs/fachthemen/irtad//english/ we2.html.

Rabkin, Matthew, et al. 2005. Appendix A, Chronology of terrorist attacks against public transit. Transit Security Design Considerations, FTA Safety and Oversight, http:// tinyurl.com/nn3xuzy.

Reconnecting America. 2009. Realizing the potential for sustainable and equitable TOD: Recommendations to the interagency partnership on sustainable communities, http://tinyurl.com/phdz9gx.

Roberts, Aki, and Steven Block. 2013. Explaining temporary and permanent motor vehicle theft rates in the United States: A crime-specific approach. Journal of Research in Crime and Delinquency, 50(3): 445-471, http://jrc.sagepub.com/content/50/3/445. abstract.

Rojas-Rueda, David, et al. 2011. Health risks and benefits of cycling in urban environments compared with car use: Health impact assessment study. BMJ, www.bmj.com/content/343/bmj.d4521.full.

Sanchez, Tomas, Q. Shen, and Z. Peng. 2004. Transit mobility, jobs access and low-income labour participation in U.S. metropolitan areas. Urban Studies 41(7): 1313-1331.

Savage, lan. 2013. Comparing the fatality risks in United States transportation across modes and over time. Research in Transportation Economics 43(1): 9-22, http://faculty. wcas.northwestern.edu/ ipsavage/436-manuscript.pdf.

Scheiner, Joachim, and Christian Holz-Rau. 2011. A residential location approach to traffic safety: Two case studies from Germany. Accident Analysis \& Prevention 43(1), January: 307-322.

Sivak, Michael, and Michael J. Flannagan. 2004. Consequences for road traffic fatalities of the reduction in flying following September 11, 2001. Transportation Research Part F: Traffic Psychology and Behaviour 7(4-5), July-September: 301-305, http://tinyurl.com/ ovgwczt.

Stucky, Thomas D., and John R. Ottensmann. 2009. Land use and violent crime. Criminology 47(4): 1009-1368, http://onlinelibrary.wiley.com/doi/10.1111/j.17459125.2009.00174.x/abstract.

Tay, Richard, Abul Azad , S. C. (Chan) Wirasinghe, and Stephen Hansen. 2013. Analysis of the influence of urban rail stations on neighbourhood crime. International Journal of Urban Sciences 17(2), http://dx.doi.org/10.1080/12265934.2013.776289.

Thompson, Clive. 2010. Clive Thompson to texters: Park the car, take the bus. Wired Magazine, www.wired.com/2010/02/st_clive_thompson_texting. 
TZD. 2011. Toward zero deaths: A national strategy on highway safety, www.towardzerodeaths.org.

Wilson, N., and G. Thomson. 2005. Deaths from international terrorism compared with road crash deaths in OECD countries. Injury Prevention 11: 332-333.

\section{About the Author}

TODD LITMAN (litman@vtpi.org) is founder and executive director of the Victoria Transport Policy Institute, an independent research organization dedicated to developing innovative solutions to transport problems. His work helps expand the range of impacts and options considered in transportation decision-making, improve evaluation methods, and make specialized technical concepts accessible to a larger audience. His research is used worldwide in transport planning and policy analysis. He has worked on numerous studies that evaluate transportation costs, benefits, and innovations and is active in several professional organizations, including the Institute of Transportation Engineers and the Transportation Research Board. 